\title{
Introduction
}

\section{Patricia Paradis*}

In September, 2012, the Centre for Constitutional Studies and the Faculty of Law, University of Alberta, in collaboration with the Legal Education Society of Alberta, hosted a day-long Constitutional Symposium for legal practitioners and students of law. Legal academics and practitioners provided stimulating and thought provoking updates on recent jurisprudence in the constitutional area, focussing on Charter ${ }^{1}$ sections 2, 7 and 15, the division of powers, aboriginal rights and the Charter and criminal law. Of the twelve papers presented at this Symposium, eight are featured in this Special Issue of the Constitutional Forum.

We begin this Special Issue with an article by Peter Sankoff. He forecasts the potential for a "perfect storm", one that could result in the use of a little-used Charter provision to deal with a some of the government's "cherished" mandatory minimum penalties. Sankoff focusses on three pressure systems at play which, when they collide, will provide the court with an opportunity to change from the "retreat and timidity" approach with which it has traditionally handled section 12 cases, to a more consistent and productive analysis for that obscure section.

Colin Feasby criticizes the Alberta Court of Appeal for its minimalist-style ruling in the Pridgen $^{2}$ case. He analyzes the U.S. and Canadian courts' respective approaches to judicial minimalism, arguing that while minimalism is consistent with the Canadian common law tradition of making decisions one case at a time, it should be guarded against by lower courts. The Pridgen case, he argues, was a missed opportunity for the court to provide guidance on the
Charter vis-á-vis universities. Jennifer Koshan carefully compares and contrasts section 7 and section 15 of the Charter as tools for disadvantaged persons challenging the harms of government (in)action. She notes the lack of success of several recent section 15 cases but reminds us that, unlike section 7 , section 15 protects against harms that are constitutionally recognized. She observes that framing government harms as violations of life, liberty or security of the person cannot be a winning strategy for all Charter claimants.

On the Aboriginal rights front, both authors express concern about the ways in which the duty to consult with Aboriginal peoples, as articulated in Haida Nation ${ }^{3}$, is being applied and interpreted by governments, tribunals and courts. Neil Reddekopp analyzes the Alberta Government's approach to implementation of the Haida Nation decision in its Consultation Policy. He argues that the Policy has unconstitutional aspects and that what appears as regulatory peace at the moment is not the result of this Policy but rather is the result of negotiated agreements which, at least in the short term, appear to benefit both First Nations and resource developers. Janna Promislow examines the duty to consult and accommodate since the Carrier Sekani ${ }^{4}$ decision of 2010. While there is reason to see progress, particularly in signalling the constitutional nature of the duty and its integration within administrative law principles, she notes that the inconsistencies with which lower courts and tribunals apply established administrative law principles appear to signal an inclination to avoid the duty. This, she concludes, undermines the process of reconciliation envisaged in Haida Nation. 
And lastly, on the reinvigorated division of powers front, Moin Yahya thoroughly examines the reasons for the Supreme Court of Canada's decision in the Reference Re Securities Act. ${ }^{5}$ He lauds the court's affirmation of established federalism jurisprudence and concludes that, given the court's decision in this case, division of powers principles are still alive and well in Canada. Dwight Newman bemoans the focus on section 7 of the Charter in Canada (AG) v PHS Community Services ${ }^{6}$. He argues that, instead of this highly activist decision that will surely have far reaching implications, the Supreme Court should have taken the opportunity to confirm and to clarify the doctrine of provincial interjurisdictional immunity in the case, thus providing a more circumscribed and case-specific ruling. And in another division of powers article in the contentious health area, Ubaka Ogbogu makes the case that where there is lack of specificity in our Constitution regarding the division of powers, the "concrete basis and reasoned apprehension of harm" threshold proposed in the AHRA Reference ${ }^{7}$ offers a better solution than existing doctrine for the demarcation of federal and provincial legislative authority over health.

These articles provide interesting analyses of recent constitutional developments and we trust you will find they provide compelling reading.

\section{Notes}

* Editor and Executive Director, Centre for Constitutional Studies.

1 Canadian Charter of Rights and Freedoms, Part I of the Constitution Act, 1982, being Schedule B to the Canada Act, 1982 (UK) 1982, c 11 [Charter].

2 Pridgen $v$ University of Calgary, 2010 ABQB 644 aff'd 2012 ABCA 139.

3 Haida Nation $v$ British Columbia (Minister of Forests), 2004 SCC 73, [2004] 3 SCR 511.

4 Rio Tinto Alcan v Carrier Sekani Tribal Council, 2010 SCC 43, [2010] 2 SCR 650.

5 Reference Re Securities Act, 2011 SCC 66, [2011] 3 SCR 837.

6 Canada (AG) v PHS Community Services,2011 SCC 44, [2011] 3 SCR 134.

7 Reference Re Assisted Human Reproduction Act, 2010 SCC 61, [2010] 3 SCR 457. 